\title{
Barriers and Facilitators of B2B Degree of Digital Use in Travel Services Supply-Chain: An integration of Operational and Behavioral perspective
}

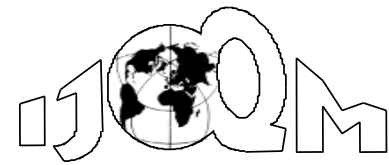

DOI: $10.46970 / 2021.27 .4 .5$

Volume 27, Number 4

December 2021, pp. 383-398

\author{
Deviprasad Ghosh \\ Institute of Management Technology \\ (IMT)Hyderabad \\ (efpm04018@iiml.ac.in)
}

The paper aimed to develop a conceptual model of determinant factors as barriers and facilitators of $B 2 B$ degree of digital use in the travel services supply chain by applying operational and behavioral theories. Based on the field study, we identified five facilitators and three barriers and added two new interorganizational barriers lack of supplier support and lack of offering flexibility in the travel services supply chain. The perceived cost was identified as an organizational factor and a facilitator. This study considered buyer firm size as a contingency variable and conceptualized it as a moderator. The study contributed to the understanding of the $B 2 B$ digital usage domain in intermediary-supplier relationships. The study suggested practical implications for the industry.

Keywords: B2B Digital usages, Behavioural and Operational Theories, Supplier-Intermediary Relationship, Travel Service Supply Chain, Conceptual Model

\section{Introduction}

The research in B2B digital adoption \&usage has focused on understanding digital adoption behaviour and minimal study to understand digital usage behaviour (Andreu et al., 2010).B2B digital usages research is mainly limited to large organizations in developed countries, and very little research on MSMEs in developing countries(Grandon and Pearson, 2004).Studies in digital adoption and usages focussed mainly on tangible products, and limited studies focussed on services, more so in the services supply chain. Moreover, very few studies are on B2B digital usages in travel services, particularly supplier-intermediary relationships (Thao and Swierczek, 2008; Bigne et al., 2008; Andreu et al., 2010; Shouk et al. 2012). Most studies have conceptualized B2B Digital usages as an innovation adoption in organizations as a unitary outcome (Wu et al., 2003). Very few studies have treated digital usages as a process-based concept in value chain activities such as supplier interface (Supplier Communication, Supplier Transaction) and the impact of digital usages on external relationships with suppliers (Andreu et al., 2010). Digital usages are continuous innovation and are explained better at a process level than a single construct (Wu et al., 2003). Therefore, the study defined digital usages as the extent to which digital processes are being used to conduct value chain activities, which can be measured by 
the breadth of use and the depth of use for each activity that has been migrated to the digital platform. (Hart and Saunders 1998).

Travel services have been considered as a context of study since online travel accounts for the largest share (61\% share) of the digital commerce market in India (IAMAI-IMRB Report, 2018). Travel services are an essential services industry, with a size of US\$ 75 billion (2020). The industry size is projected to reach US\$ 125 billion by 2027 at a CAGR of $9 \%$ (Travel markets in India Report, RedSeer Consulting, 2021). Digital travel sales contribute $41 \%$ of total travel sales and are growing by a CAGR of $17.8 \%$. (Indian Online Travel Industry Report 2015, Aranca Consulting). Digital services have created disruption in the travel services supply chain. Competition amongst intermediaries and online travel suppliers has intensified as they target customers online directly. Currently, $63 \%$ of total digital sales is contributed by Intermediaries (OTA/ RTA), and the balance is $37 \%$ by direct travel suppliers (Praxis report, Livemint, 2018). The intermediaries online travel agencies (OTA) have 57\% of total digital sales, and less than $6 \%$ of digital sales come from retail travel agencies (RedSeer Consulting 2010).Thus, this study intends to investigate the determinant factors influencing retail travel agencies and online travel suppliers' relationships.

\section{Research Objectives}

Very few studies have analyzed determinant factors ofB2B digital usage's as barriers and facilitators in travel services (Law, Leung, \& Wong, 2004; Tsai, Huang, \& Lin, 2005;Heung, 2006; Thao \&Swierczek, 2008; Shouk et al. 2012). Digital usages in the B2B travel services context have been studied either with the seller or consumer perspective but limited study with an intermediary perspective (Bigne et al., 2008; Thao and Swierczek, 2008; Andreu et al., 2010). Therefore, the study aimed to identify the determinant factors as Barriers and Facilitators of B2B Degree of Digital Use in Retail Travel Agency - Online Travel Supplier relationship.

Further, most studies in B2B digital usages have treated buyer firm size as an organizational factor and hence considered it as an antecedent factor (Brown \&Kaewkitipong, 2009; Ghobakhloo et al., 2011; Ramdani et al., 2013; Rahayu\& Day, 2015) and as a controlling factor (Wu et al., 2003; Wu et al., 2007; Zhu and Kraemer 2005; Bigne et al., 2008) in different digital contexts. Limited studies have treated Firm Size as firmographic objective information and, therefore, a contingency variable and attempted to understand its moderating effects (Sila, 2013).Thus, the study intends to understand the role of Buyer Firm Size in the influence of Barriers \& Facilitators on B2B Degree of Digital Use in Retail Travel Agency - Online Travel Supplier relationship.

\subsection{Method}

\section{Methodology}

The study employed a qualitative grounded theory (Glaser and Strauss 1967) and literature review to derive theory inductively. The sample cities are selected by applying the cluster random sampling method. The respondent travel agencies are selected based on systematic random sampling from a travel agency database. 


\subsection{Sampling Procedure}

To understand the problem of the retail travel agencies in India, we conducted field research in metro and mini-metros (Top eight cities). The study is for digital usages; therefore, our research in metros and mini-metros (Top eight cities) is relevant since top cities have achieved higher digital adoption levels. The study limited the sampling frame to the top eight cities and MSME retail travel agencies. More than 90 percent of Retail Travel Agencies in India are MSMEs with Investments in Assets less than INR 50million, and more than 56 percent of travel agencies are in the top 8 cities in India. Seventy-nine percent of travel agencies have 1-50 employees, and 84 percent of agencies have an annual turnover up toINR100 million. (USD 1428k)(Sunrise Consultancy, February 2020). The eight cities are divided into two clusters based on a population of travel agencies. Cluster 1 consists of cities with more than 1000 registered travel agencies, and cluster 2 consists of cities with less than 1000 travel agencies. Delhi was selected from cluster 1 and Hyderabad city from cluster 2. The study selected thirty MSMEs retail travel agencies based on population statistics. Retail travel agency owners/ key managers (key informants) were subjected to indepth interviews using a semi-structured questionnaire. As per the grounded theory approach (Glaser and Strauss 1967), the source's qualitative research data is coded and analyzed to develop theoretical constructs to build theory inductively. A literature review in the B2B travel services enabled the coding process and interpretation of respondents' statements into child nodes (themes) and parent nodes (constructs) using NVivo 12 software (QSR International).

\subsection{Data Analysis}

The coding process helped to identify the barriers and facilitators of B2B digital usages. The retail travel agency owners /key managers' statements, sentences, words were coded using a coding process. The barriers and facilitators conceptualization was generated inductively from the raw data, and mapped with the literature review (Taylor \& Bogdan, 1984). The analysis emphasized the data-based inductively derived findings, as previous empirical research addressing the context of the study was limiting. The open codes were developed from text varying in length from several words to paragraphs. The open coding represented an iterative process whereby themes initially identified using open coding merited further scrutiny and/or linking to the concepts in literature during axial coding. The expert opinion provided by two online travel agency managers were also used to substantiate the findings and analysis. The results were subsequently summarized and mapped with constructs and construct items from the literature. We also developed the operational definitions of the variables used in the study, adopted and modified from the literature to suit the study context.

\section{Literature Review}

As stated in the methodology, the researcher had no theory in mind at the initiation stage. Technological, Organisational, and Environmental framework (TOE) (Tornatzky\& Fleischer, 1990), the most widely used framework in empirical research in digital adoption and usages, was used to identify and categorize determinant factors impacting digital usages. Based on the framework, determinant factors were classified into three broad categories, i.e., technological, organizational, and environmental 
factors, which impact IT innovation-related decisions and the usage of technological innovations in organizations. The findings of the study pointed to the criticism of the framework by many past researchers. First, the framework does not cover contextual factors such as Inter-Organisational factors in a B2B context. (Sila, 2013), therefore it provides an incomplete explanation for behavioral aspects of buyer-supplier relationships. Second, the framework does not distinguish Organizational objective information (Organization Size) from Organizational factors such as Organizational IT weakness (Thao and Swierczek, 2008);, Organizational Culture (Huang, 2006), Organizational Strategic Intent (Raymond, 2001). The context of the study is the Retail Travel Agency- Online Travel Supplier relationship in the B2B services supply chain. The study identified the determinant factors based on a literature search in B2B travel services. The identified determinant factors as technological, environmental, organizational, and inter-organizational as per empirical studies in B2B travel services context are categorized into Perceived Barriers and Perceived Facilitators. The study also investigated the identified determinant factors in other B2B services contexts to understand construct, construct definition, and operationalization. The following Tables present a categorization of determinant factors into perceived barriers (see Table 1) \& perceived facilitators (see Table 2) based on relevant literature review.

Table 1 Perceived Barriers of B2B Digital Use in Travel Services

\begin{tabular}{|c|c|c|c|c|}
\hline \multirow{2}{*}{$\begin{array}{c}\text { Perceived } \\
\text { Barriers }\end{array}$} & \multirow{2}{*}{ Definition (Source) } & \multirow{2}{*}{$\begin{array}{l}\text { Type of } \\
\text { Factors }\end{array}$} & \multicolumn{2}{|c|}{ B2B Context } \\
\hline & & & $\begin{array}{l}\text { Travel } \\
\text { Services }\end{array}$ & Other Services \\
\hline $\begin{array}{l}\text { IT } \\
\text { Infrastructure } \\
\text { Problems }\end{array}$ & $\begin{array}{l}\text { Lack of public infrastructure } \\
\text { readiness in terms of Internet } \\
\text { access, availability, and fast }\end{array}$ & $\begin{array}{l}\text { Technological } \\
\text { Factors }\end{array}$ & $\begin{array}{l}\text { Thao and } \\
\text { Swierczek } \\
\text { (2008); Shouk }\end{array}$ & $\begin{array}{l}\text { Teo et al. } \\
(2006) ; \text { Shree et } \\
\text { al. (2021). }\end{array}$ \\
\hline $\begin{array}{l}\text { Perceived } \\
\text { Security Risk }\end{array}$ & $\begin{array}{l}\text { Security Risk is a threat that } \\
\text { creates circumstances, conditions, } \\
\text { or events that can cause economic }\end{array}$ & $\begin{array}{l}\text { Technological } \\
\text { Factors }\end{array}$ & \begin{tabular}{|l|} 
Thao and \\
Swierczek, \\
(2008); Shouk
\end{tabular} & $\begin{array}{l}\text { Kaynak et al. } \\
\text { (2005); Oliveira } \\
\text { and Martins } \\
\end{array}$ \\
\hline $\begin{array}{l}\text { Lack of } \\
\text { Critical Mass }\end{array}$ & $\begin{array}{l}\text { The relatively large number of } \\
\text { customers and suppliers not being } \\
\text { online and decreasing productivity }\end{array}$ & $\begin{array}{l}\text { Environmental } \\
\text { Factors }\end{array}$ & \begin{tabular}{|l|} 
Shouk et al. \\
(2012); Field \\
Study, (2018) \\
\end{tabular} & $\begin{array}{l}\text { Kaynak et al. } \\
\text { (2005); Shree et } \\
\text { al. (2021). } \\
\end{array}$ \\
\hline $\begin{array}{l}\text { Lack of } \\
\text { offering } \\
\text { flexibility }\end{array}$ & $\begin{array}{l}\text { Lack of Offering Flexibility refers } \\
\text { to online suppliers' lack of } \\
\text { flexibility in product, services \& }\end{array}$ & $\begin{array}{l}\text { Inter- } \\
\text { Organizational } \\
\text { Factors } \\
\end{array}$ & $\begin{array}{l}\text { Field Study, } \\
\text { (2018) }\end{array}$ & $\begin{array}{l}\text { Ozer, (2002); } \\
\text { Saghiri\& Barnes, } \\
\text { (2016); Chahal et }\end{array}$ \\
\hline $\begin{array}{l}\text { Lack of } \\
\text { Supplier } \\
\text { Support }\end{array}$ & $\begin{array}{l}\text { Lack of Supplier Support refers to } \\
\text { poor post-sales support in customer } \\
\text { cancellation refunds, customer }\end{array}$ & \begin{tabular}{|l|} 
Inter- \\
Organizational \\
Factors \\
\end{tabular} & $\begin{array}{l}\text { Field Study, } \\
\text { (2018) }\end{array}$ & $\begin{array}{l}\text { Eggert et al., } \\
(2006) ; \text { Blocker, } \\
(2011) ;\end{array}$ \\
\hline
\end{tabular}

\section{Proposed Theoretical Framework}

Past studies in the domain have applied technology perspective to develop conceptual models and explain the usages behavior of the firm, such as the TOE framework (Teo et al. 2006; Ghobakhloo et al., 2011; Sila, 2013), Diffusion of Innovation theory (Zhu et al. 2006a), the Institutional Theory (Teo et al. 2003; Penttinen\&Tuunainen, 2009), and the Iacovou et al. model (Oliveira and Matins, 2010b). Few studies used behavioral theories, such as Agency Theory, Culture Theory, to explain organizational behavioral antecedents. Although the studies provided an understanding of technology 
Table 2 Perceived Facilitators of B2B Digital Use in Travel Services

\begin{tabular}{|c|c|c|c|c|}
\hline \multirow{2}{*}{$\begin{array}{c}\text { Perceived } \\
\text { Facilitators }\end{array}$} & \multirow{2}{*}{ Definition (Source) } & \multirow{2}{*}{$\begin{array}{l}\text { Type of } \\
\text { Factors }\end{array}$} & \multicolumn{2}{|r|}{ B2B Context } \\
\hline & & & Travel Services & Other Services \\
\hline $\begin{array}{l}\text { Perceived } \\
\text { Relative } \\
\text { Advantage }\end{array}$ & $\begin{array}{l}\text { The degree to which } \\
\text { perception of innovation is } \\
\text { that it is better than the } \\
\text { idea it supersedes. } \\
\text { (Rogers, 1983) }\end{array}$ & $\begin{array}{l}\text { Technological } \\
\text { Factors }\end{array}$ & \begin{tabular}{|l|} 
Thao and \\
Swierczek, \\
$(2008) ;$ \\
Raymond, \\
(2001); Shouk et \\
al. (2012); Field \\
Study, (2018) \\
\end{tabular} & $\begin{array}{l}\text { Kaynak et al. (2005); } \\
\text { Ghobakhloo et al. (2011); } \\
\text { Rahayu and Day, (2015); } \\
\text { Ramdani et al., (2013); Zhu } \\
\text { et al. (2006); Sila, (2015); } \\
\text { Shree et al. (2021). }\end{array}$ \\
\hline \begin{tabular}{|l|} 
Perceived \\
Compatibility \\
\end{tabular} & $\begin{array}{l}\text { The degree to which } \\
\text { perception of innovation is } \\
\text { consistent with existing } \\
\text { values, past experiences, } \\
\text { and potential adopters' } \\
\text { needs. (Rogers, 1983) }\end{array}$ & $\begin{array}{l}\text { Technological } \\
\text { Factors }\end{array}$ & $\begin{array}{l}\text { Shouk et al. } \\
(2012) ; \\
\text { Raymond, } \\
(2001) ; \text { Field } \\
\text { Study, (2018) }\end{array}$ & $\begin{array}{l}\text { Kaynak et al. (2005); } \\
\text { Ghobakhloo et al. (2011); } \\
\text { Rahayu and Day, (2015); } \\
\text { Ramdani et al., (2013); Zhu } \\
\text { et al. (2006); Sila, (2015); } \\
\text { Shree et al. (2021). }\end{array}$ \\
\hline Perceived Cost & $\begin{array}{l}\text { Perceived cost is the } \\
\text { degree of cost advantage } \\
\text { to organizations (Sila, } \\
\text { 2013) }\end{array}$ & $\begin{array}{l}\text { Organizational } \\
\text { Factors }\end{array}$ & $\begin{array}{l}\text { Field Study, } \\
\text { (2018) }\end{array}$ & $\begin{array}{l}\text { Sila, (2013); Kaynak et al. } \\
\text { (2005); Bigne et. al., (2008); }\end{array}$ \\
\hline $\begin{array}{l}\text { Supplier } \\
\text { Pressure }\end{array}$ & $\begin{array}{l}\text { Supplier (Coercive) } \\
\text { pressures are formal or } \\
\text { informal forces exerted on } \\
\text { organizations by other } \\
\text { organizations upon which } \\
\text { the former organizations } \\
\text { depend. (Penttinen and } \\
\text { Tuunainen, 2009) }\end{array}$ & \begin{tabular}{|l} 
\\
Environmental \\
Factors
\end{tabular} & $\begin{array}{l}\text { Bigne et. al., } \\
\text { (2008); } \\
\text { Raymond, } \\
(2001) ; \text { Field } \\
\text { Study, (2018) }\end{array}$ & $\begin{array}{l}\text { Penttinen and Tuunainen, } \\
\text { (2009); Rahayu and Day, } \\
\text { (2015); Sila, (2013); } \\
\text { Ghobakhloo et. al, (2011); } \\
\text { Sila, (2015). }\end{array}$ \\
\hline $\begin{array}{l}\text { Customer } \\
\text { Pressure }\end{array}$ & $\begin{array}{l}\text { Customers actively } \\
\text { influence the system to } \\
\text { change according to their } \\
\text { requirements, allowing the } \\
\text { supplier to adjust the } \\
\text { system to accommodate } \\
\text { the customer better. (Wu } \\
\text { \& Lee, 2005) }\end{array}$ & $\begin{array}{l}\text { Environmental } \\
\text { Factors }\end{array}$ & $\begin{array}{l}\text { Bigne et al., } \\
(2008) ; \text { Andreu } \\
\text { et al., (2010); } \\
\text { Field Study, } \\
(2018)\end{array}$ & $\begin{array}{l}\text { Wu et al., (2003); Rahayu } \\
\text { and Day, (2015); } \\
\text { Ghobakhloo et al., (2011); } \\
\text { Sila, (2015). }\end{array}$ \\
\hline $\begin{array}{l}\text { Industry } \\
\text { Pressure }\end{array}$ & $\begin{array}{l}\text { When faced with a } \\
\text { problem from ambiguous } \\
\text { causes, an organization } \\
\text { imitates similar } \\
\text { organizations in the } \\
\text { industry that it perceives } \\
\text { as more legitimate or } \\
\text { successful. (Wu \& Lee, } \\
\text { 2005) }\end{array}$ & $\begin{array}{l}\text { Environmental } \\
\text { Factors }\end{array}$ & $\begin{array}{l}\text { Andreu et al., } \\
\text { (2010); Field } \\
\text { Study, (2018) }\end{array}$ & $\begin{array}{l}\text { Wu et al., (2003); Wu et al., } \\
\text { (2007); Rahayu and Day, } \\
\text { (2015); Sila, (2013); } \\
\text { Ramdani et al., (2013); Zhu } \\
\text { and Kraemer (2005); Zhu et } \\
\text { al. (2003); Oliveira and } \\
\text { Martins (2011); Teo et al. } \\
\text { (2006); Zhu et al. (2006); } \\
\text { Sila, (2015); Shree et al. } \\
\text { (2021). }\end{array}$ \\
\hline
\end{tabular}

adoption and users' usage behavior in a different context, the model gave an incomplete understanding of the inter-organizational behavior of the firms in an exchange relationship. Few studies addressed the issue by using more than one model in combination (Zhu et al. 2006a; Gibbs and Kraemer 2004; Hsu et al., 2006). But the theories seemed to be limited to addressing the issue of supply chain context, particularly the services supply-chain. The theory cannot explain all types of factors, such as moderation factors or antecedent factors like inter-organizational factors. The 
research findings suggest that an integrated approach of technology with operational and behavioral perspective can provide a complete explanation of the interorganizational relationships and Inter-organizational systems (IOSs) adoption and usages. We find from the literature review; there is a negligible exploration of interorganizational theories with a behavioral perspective in Information Technology Systems. This study, therefore, has integrated the behavioral theory Social Exchange Theory (SET) from the domain Social Psychology and Triad Theory (TT) from Supply-Chain Management to develop the proposed theoretical framework. (See Figure 1)

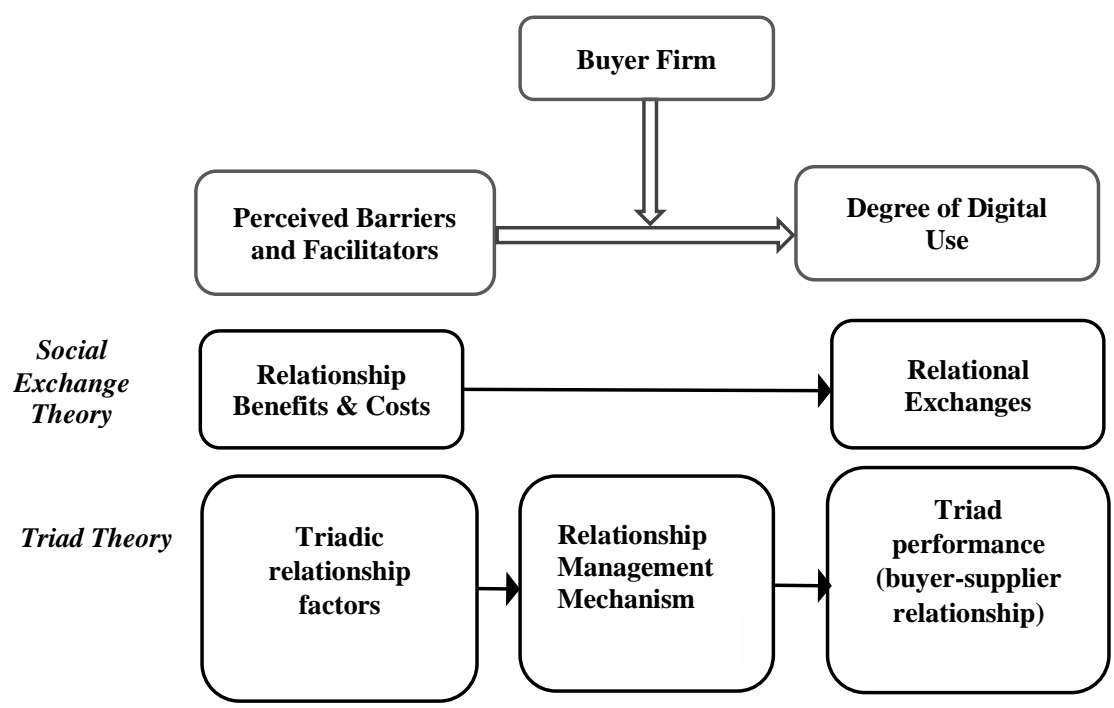

Figure 1 Proposed Theoretical Framework

Behavioral perspective: Social Exchange Theory (George Homans, 1958; Blau, 1964; Emerson, 1976) states that Organisations will evaluate outcomes and motivation to comply basis Cost-Benefit assessment while forming relationships. The theory proposes that the relationship an organization develops and maintains are the ones that maximize relationship benefits and minimize relationship costs. An organization feels positive or negative towards a relationship basis outcome of three factors - cost-benefit analysis, comparison level, and comparison level alternatives. Thus Barriers are interpreted as "relationship costs" that impact negatively on the Degree of Digital Use, and Facilitators are interpreted as "relationship benefits" that positively affect the Degree of Digital Use.

Operational perspective: Triad Theory (Simmel, 1955, 1971; Cook and Emerson, 1984): Simmel's work $(1955,1971)$ focussed on the different roles that the third member in a triad can take, which will influence the exchange dynamics of the other two members. The role of the third member can be one who facilitates the relationship between the other two members or creates a conflict situation between the other two members or exploits the situation where the other two members are not directly connected. On the other hand, Cook and Emerson (1984) studied both direct and 
indirect influences in an exchange relationship. The two exchange relations are connected to the extent that exchanges in one relation are contingent (positively or negatively) upon exchanges in the other ties. Applying Simmel's model in our study context, the buyer (retail travel agency), the supplier (online travel supplier), and the supplier systems (digital travel system) can be considered as three members in a triadic relationship (buyer/supplier/supplier systems). Therefore, triad members influence the relationship of other two members that is the buyer (retail travel agencies firm size) influences the supplier-supplier systems relationship (that is, formation of barriers and facilitators of digital travel systems); the supplier (online travel suppliers) affects supplier systems - buyer relationship (that is the degree of digital use by retail travel agencies), and the supplier systems (digital travel systems) influence the buyersupplier relationship (that is buyer-supplier service exchanges). Cook and Emerson (1984) suggest that buyer-supplier systems relationships, supplier-supplier systems relationships, and buyer-supplier relationships will positively or negatively impact each other.

\subsection{Firm Profile}

\section{Findings and Discussions}

The field study (2018) showed that digital usages in MSMEs retail travel agencies are limited to lower-level digital communications use (72\%) such as email,e-informations, and minimal higher-level digital transactions use (49\%) such as e-purchases, epayments. However, there is minimal variation in the degree of digital use for large firms versus smaller firms (see Table 3).

Table 3 Firm Characteristics

\begin{tabular}{|l|c|c|c|c|c|c|c|}
\hline $\begin{array}{c}\text { Firm } \\
\text { category }\end{array}$ & $\begin{array}{c}\text { Investment } \\
\text { levels in } \\
\text { equipment } \\
\text { (Assets) }\end{array}$ & $\begin{array}{c}\text { No. of } \\
\text { employees }\end{array}$ & $\begin{array}{c}\text { No. of } \\
\text { retail } \\
\text { travel } \\
\text { agency }\end{array}$ & $\begin{array}{c}\text { Travel agency } \\
\text { business (in } \\
\text { completed } \\
\text { years) }\end{array}$ & $\begin{array}{c}\text { Online travel } \\
\text { services } \\
\text { business (in } \\
\text { completed } \\
\text { years) }\end{array}$ & $\begin{array}{c}\text { Share of online } \\
\text { communications }\end{array}$ & $\begin{array}{c}\text { Share of } \\
\text { online } \\
\text { transactions }\end{array}$ \\
\hline $\begin{array}{l}\text { Small } \\
\text { firm }\end{array}$ & $\begin{array}{l}\text { Less than INR 1 } \\
\text { million (USD } \\
\text { 14k) }\end{array}$ & $1-10$ & 6 & 15.9 & 8.3 & $70 \%$ & $49 \%$ \\
\hline $\begin{array}{l}\text { Medium } \\
\text { firm }\end{array}$ & $\begin{array}{l}\text { INR 1 million to } \\
\text { less than INR 20 } \\
\text { million (USD } \\
\text { 285k) }\end{array}$ & $11-50$ & 12 & 16.7 & 8.6 & $80 \%$ & $50 \%$ \\
\hline $\begin{array}{l}\text { Large } \\
\text { firm }\end{array}$ & $\begin{array}{l}\text { INR 20 million to } \\
\text { less than INR 50 } \\
\text { million (USD } \\
\text { 714k) }\end{array}$ & $51-250$ & 12 & 16.7 & 8.4 & $70 \%$ & $49 \%$ \\
\hline \multicolumn{1}{|l}{ TOTAL } & & $\mathbf{3 0}$ & $\mathbf{1 6 . 5}$ & $\mathbf{8 . 4}$ & $\mathbf{7 2 \%}$ & $\mathbf{4 9 \%}$ \\
\hline
\end{tabular}

\subsection{Outcome: Degree of the Digital use of Supplier's Digital Travel Systems}

B2B Digital Usages have been defined in the literature in many ways. (a) Usages Scope - Digital use for a number of different activities in the value chain such as supplier interface, customer interface, internal operations, sales \& marketing, customer service (Gibbs and Kraemer, 2004); (b) Number of Digital Application Use - Applications use such as email, Intranet, Extranet, EDI, Websites, etc.(Grandon and Pearson, 2004; Ghobakhloo et al., 2011); (c) Usage Intensity - Digital Usage as a share of Total Usage for different activities in the value chain (Zhu and Kraemer, 2005); 
Literature review in a processes-based approach to digital usages has defined digital uses into two levels - Digital Communications and Digital Transactions (Wu et al., 2007; Wu et al., 2003, Andreu et al., 2010, Bigne et al., 2008).For this study, we operationalized digital usages in the supplier interface as the digital use of the supplier's Digital Travel Systems \& processes for various travel services activities. The degree of digital use is measured in terms of the width of usages in a value-chain activity and the depth of usage of each activity (Hart and Saunders 1998). Social Exchange Theory suggests that degree of digital use (DDU) is a relational exchanges outcome based on relationship benefits and relationship cost analysis by retail travel agencies. An increase in DDU reflects a positive relationship, and a decrease in DDU indicates a negative relationship.

\subsection{Influence of Perceived Facilitators on the Degree of Digital use}

According to Social Exchange Theory (SET), the perceived facilitators act as Relationship Benefits and, therefore, will positively affect the degree of digital use. As reported in Table 4, the study identified technological factors - Perceived Relative Advantage, Perceived Compatibility as determinant factors impacting digital adoption $\&$ usages. These are the two factors stated in the study of Diffusion of Innovation (Roger, 2003). Field study conceptualized Perceive Cost as initial technology investment and operational cost as low for digital usages. According to Transaction Costs Economics Theory (Williamson, 1975), organizations reduce transaction costs and risks when interacting with each other. Most studies in the literature on Digital Adoptions \& Usages had defined Cost as Technology Cost as a barrier. (Ghobakhloo et al., 2011; Rahayu\& Day, 2015; Zhu et al., 2006; Shouk et al., 2012). Sila (2013), in his research of EDP adoption amongst SMEs in developing countries, has considered indirect operational cost as a facilitator. In their study, Kaynak et al. (2005) have considered many cost components and defined two constructs- cost disadvantages and cost reduction. Considering fewer cost components to define cost as a construct may give an incorrect relationship for cost construct, and at best, can be defined as a cost component only. We made a comprehensive definition of Perceived Cost for digital usages by considering multiple cost themes and components. For the study, we defined perceived cost as the degree of cost advantages to organization in technology investments (Hardware/Software, training), indirect operational cost (general operating cost, communication cost) and direct operational cost (sales staff cost and transaction cost) components as a facilitator (Field Study, 2018), and has a positive impact on the B2B Degree of Digital Use. Since we have comprehensively defined Perceived Cost with multiple cost components related to digital usages, it is categorized as an Organizational factor. Burt (1987), in his study, suggests that organizations are subjected to external pressures to be isomorphic with their environment. The institutional theory (DiMaggio and Powell, 1983) states that the institutional environment can strongly influence formal structures in an organization, often more profoundly than market pressures. In the study, Coercive (Supplier) pressure, Mimetic (Customer) pressure, and Normative (Industry) pressures to act as Environmental facilitators impact the Degree of Digital Use positively. Hence, the following hypotheses for perceived facilitators were developed: 
H1 (a-f): Perceived facilitators (a) Perceived relative advantage (b) Perceived compatibility (c) Perceived cost (d) Supplier pressure (e) Customer pressure (f) Industry pressure has a positive influence on the degree of digital use of the retail travel agency.

Table 4 Perceived Facilitators of B2B Digital usages for Retail Travel Agency-Online Travel Supplier Relationship

\begin{tabular}{|c|c|c|}
\hline Perceived Facilitators & Discussion themes (Construct items) & \begin{tabular}{|l} 
Respondents' verbatim: \\
statements/ phrases/ words
\end{tabular} \\
\hline \multirow{8}{*}{$\begin{array}{l}\text { Facilitator 1: Perceived } \\
\text { relative advantage (Shouk et } \\
\text { al., 2012) }\end{array}$} & $\begin{array}{l}\text { Better customer service (Kaynak et al. } \\
2005 \text { ) }\end{array}$ & $\begin{array}{l}\text { "We can provide the customers with the } \\
\text { kind of service they want at any time." }\end{array}$ \\
\hline & $\begin{array}{l}\text { New opportunities. (Ghobakhloo et al., } \\
\text { 2011) }\end{array}$ & "Increase in the number of customers." \\
\hline & $\begin{array}{l}\text { Saves in service time (Ghobakhloo et al., } \\
\text { 2011) }\end{array}$ & "It takes less time to book a ticket." \\
\hline & $\begin{array}{l}\text { Provides convenience (Ghobakhloo et al., } \\
\text { 2011) }\end{array}$ & $\begin{array}{l}\text { "From any place, we can check the } \\
\text { availability of bookings." }\end{array}$ \\
\hline & $\begin{array}{l}\text { Improves job performance (Ghobakhloo } \\
\text { et al., 2011) }\end{array}$ & $\begin{array}{l}\text { "Providing direct ticket and confirmation } \\
\text { of the seat." }\end{array}$ \\
\hline & \begin{tabular}{|l|} 
Better communication (Kaynak et al., \\
$2005)$
\end{tabular} & "Easy communication on the internet." \\
\hline & $\begin{array}{l}\text { Increases profitability (Ghobakhloo et al., } \\
\text { 2011) }\end{array}$ & $\begin{array}{l}\text { "Get a huge amount of profits on the } \\
\text { internet booking." }\end{array}$ \\
\hline & Increases sales (Kaynak et al., 2005) & $\begin{array}{l}\text { "By using online bookings, we can expand } \\
\text { our sales." }\end{array}$ \\
\hline \multirow{4}{*}{$\begin{array}{l}\text { Facilitator 2: Perceived } \\
\text { compatibility (Shouk et al. } \\
\text { 2012) }\end{array}$} & $\begin{array}{l}\text { Compatible with existing business } \\
\text { (Ghobakhloo et al., 2011) }\end{array}$ & $\begin{array}{l}\text { "Business growth is much improved } \\
\text { online." } \\
\text { "Increase in customer satisfaction." }\end{array}$ \\
\hline & $\begin{array}{l}\begin{array}{l}\text { Compatible with existing processes \& } \\
\text { systems (Ghobakhloo et al., 2011) }\end{array} \\
\end{array}$ & $\begin{array}{l}\text { "It always helps in the easy way of } \\
\text { business." }\end{array}$ \\
\hline & \begin{tabular}{|l|} 
Compatible with company culture and \\
values (Ghobakhloo et al., 2011) \\
\end{tabular} & \begin{tabular}{|l|} 
"Provide the best service to our \\
customers."
\end{tabular} \\
\hline & \begin{tabular}{|l|}
$\begin{array}{l}\text { Compatible with preferred work practices } \\
\text { (Ghobakhloo et al., 2011) }\end{array}$ \\
\end{tabular} & "We can be sure about our services." \\
\hline \multirow{5}{*}{$\begin{array}{l}\text { Facilitator 3: Perceived Cost } \\
\text { (Field Study, 2018; Bigne et } \\
\text { al., 2008) }\end{array}$} & Less investment (Sila, 2013) & $\begin{array}{l}\text { "Less investment. It's like nothing to invest } \\
\text { in online business." }\end{array}$ \\
\hline & Less operating cost (Kaynak et. al., 2005) & $\begin{array}{l}\text { "The cost has become less for us by using } \\
\text { online booking services." }\end{array}$ \\
\hline & $\begin{array}{l}\text { Less communication cost (Bigne et al., } \\
\text { 2008) }\end{array}$ & $\begin{array}{l}\text { "Without spending any amount, we can } \\
\text { advertise our brand, communicate with } \\
\text { suppliers, customers." }\end{array}$ \\
\hline & Less transaction cost (Bigne et al., 2008) & "Less of cost for online bookings." \\
\hline & $\begin{array}{l}\text { Fewer sales staff costs (Kaynak et al., } \\
\text { 2005) }\end{array}$ & $\begin{array}{l}\text { "If there is no internet, there will be an } \\
\text { increase in manpower, and no savings are } \\
\text { possible." }\end{array}$ \\
\hline \multirow{2}{*}{$\begin{array}{l}\text { Facilitator 4: } \\
\text { Supplier pressure (Bigne et al., } \\
\text { 2008) }\end{array}$} & $\begin{array}{l}\text { Travel agencies depend on online travel } \\
\text { supplier resources. (Penttinenand } \\
\text { Tuunainen, 2009) }\end{array}$ & "Offshore travel required online portals." \\
\hline & $\begin{array}{l}\text { Travel agencies depend upon core travel } \\
\text { suppliers in the industry. (Penttinenand } \\
\text { Tuunainen, 2009) }\end{array}$ & "Tickets refunding is always online." \\
\hline \multirow{2}{*}{$\begin{array}{l}\text { Facilitator 5: Customer } \\
\text { pressure (Bigne et al., 2008) }\end{array}$} & $\begin{array}{l}\text { Customers expect online offers from } \\
\text { travel agencies. (Wu and Lee, 2005) }\end{array}$ & $\begin{array}{l}\text { "Customer offers for direct online } \\
\text { booking." }\end{array}$ \\
\hline & $\begin{array}{l}\text { Customers want online travel bookings. } \\
\text { (Wu and Lee, 2005) }\end{array}$ & $\begin{array}{l}\text { "Offshore travelers prefer online } \\
\text { bookings." }\end{array}$ \\
\hline \multirow{2}{*}{$\begin{array}{l}\text { Facilitator 6: } \\
\text { Industry pressure (Andreu et } \\
\text { al., 2010) }\end{array}$} & $\begin{array}{l}\text { Most travel agencies will ultimately adopt } \\
\text { digital travel services practices. (Wu et } \\
\text { al., 2003) }\end{array}$ & $\begin{array}{l}\text { "In the long run, all types of travel agents } \\
\text { will have to use it." }\end{array}$ \\
\hline & $\begin{array}{l}\text { Most competitors have already adopted } \\
\text { digital travel systems. (Wu et al.,2003) }\end{array}$ & $\begin{array}{l}\text { "Nowadays, most of the travel agencies } \\
\text { are using an online booking system." }\end{array}$ \\
\hline
\end{tabular}




\subsection{Influence of Perceived Barriers on the Degree of Digital use}

According to Social Exchange Theory, perceived barriers will act as Relationship Costs and negatively impact the degree of digital use. As reported in Table 5, Iacovouet al. Model (1995) explained the characteristics of inter-organizational systems (IOSs) that influence IT adoption and usages. It identifies three factors Perceived Benefits or Obstacles, Organisational Readiness or Weaknesses, and External Pressure or issues. The technological factors lack IT Infrastructure Readiness in terms of availability, connectivity, reliability, cost of internet, and telecommunication network (Kenneth et al., 2012); the Security riskarising from company data safety on the internet. The external environmental issue - Lack of Critical Mass to achieve efficiency in digital operations due to a limited number of buyers and suppliers, has been identified as a critical factor for the slow digital adoption \& usages of MSMEs. Thus, IT Infrastructure Problems, Perceived Security risks, and Lack of Critical Mass negatively impact the degree of digital use.

The field study identified two Inter-organizational factors as perceived barriersLack of Offering Flexibility and Lack of Supplier Support that are not in existing literature in the domainB2B Travel Services. Lack of Offering Flexibility refers to online suppliers' unwillingness to offer modifications of confirmed bookings, the opportunity for customization in products/ packages, and exclusive offers for online bookings (Field Study, 2018). Lack of Supplier Support refers to suppliers' low postsales services in customer refunds, customer travel issues, poor supplier responses, no dedicated service staff assigned to attend to Travel Agency issues, and attitude/behavioral responses of support staff in personal interactions (Field Study, 2018). Sila (2013), in his study of SMEs in developing countries, identified Supplier Trust; Bigne et al. (2008), in their survey of travel agencies in Spain, identified B2B relationship intensity; and Lama et al. (2020) in their tourism research in Nepal, identified Lack of Supplier Trust as an inter-organizational factor. According to Agency theory (Eisenhardt, 1989), the online travel suppliers (Principal) drive to align the behaviours or outcomes of the other parties-retail travel agencies (Agents) to their expectations. The management of Inter-organizational relationships between Principal and Agent is through contracts based on incentives and co-operations. Therefore, based on the study, the following hypotheses for perceived barriers were developed:

H2 (a-e): Perceived barriers (a) IT infrastructure problem (b) Perceived security risk (c) Lack of critical mass (d) Lack of supplier support (e) Lack of offering flexibility, has a negative influence on the degree of digital use of the retail travel agency.

\subsection{Buyer Firm Size as Moderator}

Factors such as Firm size, Firm type is an objective measure of Firm Characteristics and not internal factor of a firm. Therefore, the study has not considered it an organizational factor and assessed its direct effects but conceptualized it as a moderator. According to Resource-Based-View (RBV) framework (Barney 1991), organizational size reflects the organization's IT capability and slack resources (Zhu and Kraemer, 2005; Tornatzky and Fleischer, 1990). Large organizations will have surplus resources, ITskilled employees, and experience to manage uncertainty and risk easily than relatively more minor organizations (Levenburg et al., 2006; Yap, 1990; Sila, 2013). The field study suggested that large retail travel agencies perceived more facilitators and fewer barriers while smaller retail travel agencies perceived more 
Table 5 Perceived Barriers of B2B Digital usages for Retail Travel Agency - Online Travel Supplier Relationship

\begin{tabular}{|c|c|c|}
\hline Perceived Barriers & $\begin{array}{c}\begin{array}{c}\text { Discussion themes (Construct items from } \\
\text { source) }\end{array} \\
\end{array}$ & $\begin{array}{c}\text { Respondents' verbatim statements/ } \\
\text { sentences / words: }\end{array}$ \\
\hline \multirow{3}{*}{$\begin{array}{l}\text { Barrier 1: } \\
\text { IT infrastructure problems } \\
\text { (Thao and Swierczek, } \\
\text { 2008) }\end{array}$} & $\begin{array}{l}\text { Low speed of internet accessibility. (Thao and } \\
\text { Swierczek, 2008) }\end{array}$ & $\begin{array}{l}\text { "Some time there will be an issue with } \\
\text { internet speed." }\end{array}$ \\
\hline & $\begin{array}{l}\text { The high cost of internet accessibility. (Thao } \\
\text { and Swierczek, 2008) }\end{array}$ & $\begin{array}{l}\text { "If there are no smartphones, it will be } \\
\text { costly to use the internet.." }\end{array}$ \\
\hline & $\begin{array}{l}\text { Poor IT infrastructure readiness. (Thao and } \\
\text { Swierczek, 2008) }\end{array}$ & $\begin{array}{l}\text { "Internet error in some cases." "Agents' } \\
\text { online portal with the internet gives } \\
\text { problem sometimes." }\end{array}$ \\
\hline \multirow{3}{*}{$\begin{array}{l}\text { Barrier 2: } \\
\text { Perceived security risk } \\
\text { (Thao and Swierczek, } \\
\text { 2008) }\end{array}$} & $\begin{array}{l}\text { Company data can be hacked from computers. } \\
\text { (Thao and Swierczek, 2008) }\end{array}$ & $\begin{array}{l}\text { "Nothing is kept safe about ticket data } \\
\text { online." }\end{array}$ \\
\hline & $\begin{array}{l}\text { Need face-to-face transactions with travel } \\
\text { suppliers. (Thao and Swierczek, 2008) }\end{array}$ & "No face of communication." \\
\hline & $\begin{array}{l}\text { Documents over the internet can be accessed. } \\
\text { (Kaynak et al.,2005) }\end{array}$ & "Nothing is kept secret on the internet." \\
\hline \multirow{2}{*}{$\begin{array}{l}\text { Barrier 3: } \\
\text { Lack of critical mass } \\
\text { (Shouk et al.,2012) }\end{array}$} & $\begin{array}{l}\text { Most of the suppliers are offline. Kaynak et al. } \\
2005 \text { ) }\end{array}$ & $\begin{array}{l}\text { "The maximum number of suppliers do } \\
\text { not have access to the internet." }\end{array}$ \\
\hline & $\begin{array}{l}\text { A limited number of consumers prefer online } \\
\text { bookings. (Kaynak et al. 2005) }\end{array}$ & $\begin{array}{l}\text { "Only the young generation has an idea } \\
\text { of the use of online portals." }\end{array}$ \\
\hline \multirow{4}{*}{$\begin{array}{l}\text { Barrier 4: } \\
\text { Lack of offering flexibility } \\
\text { (Field Study, 2018, Ozer, } \\
\text { 2002) }\end{array}$} & $\begin{array}{l}\text { Ability to modify different features of the } \\
\text { existing products quickly and easily. Saghiri \& } \\
\text { Barnes, (2016) }\end{array}$ & "Lack of flexibility in online portals." \\
\hline & $\begin{array}{l}\text { Suppliers' ability to respond to our request for } \\
\text { changes in service modifications Chahal et al. } \\
(2018)\end{array}$ & $\begin{array}{l}\text { "Unwilling to make changes after order } \\
\text { bookings as per customer requirements." }\end{array}$ \\
\hline & $\begin{array}{l}\text { Ability to follow a flexible pricing policy for } \\
\text { the entire range of products. Kumar Shalender } \\
(2017)\end{array}$ & $\begin{array}{l}\text { "No discounts offered for online } \\
\text { booking." }\end{array}$ \\
\hline & $\begin{array}{l}\text { Ability to modify different features of } \\
\text { different products to the customer's } \\
\text { specifications. Saghiri \& Barnes, (2016) }\end{array}$ & $\begin{array}{l}\text { "It could be a problem to adjust to } \\
\text { customers' requirements." }\end{array}$ \\
\hline \multirow{6}{*}{$\begin{array}{l}\text { Barrier 5: } \\
\text { Lack of supplier support } \\
\text { (Field Study, 2018; } \\
\text { Blocker, 2011) }\end{array}$} & $\begin{array}{l}\text { Long customer refund period from suppliers. } \\
\text { (Blocker, 2011) }\end{array}$ & $\begin{array}{l}\text { "Refund is the biggest problem, } \\
\text { refunding money delays to customers." }\end{array}$ \\
\hline & $\begin{array}{l}\text { Customer travel issues not attended by } \\
\text { suppliers. (Blocker, 2011) }\end{array}$ & $\begin{array}{l}\text { "Service providers do not attend to my } \\
\text { customers." }\end{array}$ \\
\hline & $\begin{array}{l}\text { Poor after-sales services to travel agency } \\
\text { issues. (Eggert et al., 2006) }\end{array}$ & $\begin{array}{l}\text { "They create problems by making no } \\
\text { contact after online booking." }\end{array}$ \\
\hline & $\begin{array}{l}\text { No dedicated support staff for travel agencies } \\
\text { issues. (Blocker, 2011) }\end{array}$ & $\begin{array}{l}\text { "Every time we are supposed to } \\
\text { communicate with a new person and tell } \\
\text { him about the whole story." }\end{array}$ \\
\hline & $\begin{array}{l}\text { The Support Staff of Supplier do attend to } \\
\text { services after office hours. (Blocker, 2011) }\end{array}$ & $\begin{array}{l}\text { "They never attend to our needs in odd } \\
\text { hours." }\end{array}$ \\
\hline & $\begin{array}{l}\text { The support staff of the travel supplier is not } \\
\text { very helpful in personal interactions with our } \\
\text { people. (Blocker, 2011) }\end{array}$ & $\begin{array}{l}\text { "We always use the internet for all } \\
\text { online booking for our services, but they } \\
\text { are not very helpful." }\end{array}$ \\
\hline
\end{tabular}

barriers and fewer facilitators in the external environment. According to Triad Theory, buyer firm size will influence the barriers and facilitator relationship with the degree of digital use as a facilitator or hindrance. Based on the RBV and Triad Theory, an increase in firm size will facilitate the relationship, and a decrease will have the opposite effect. Most literature has treated MSMEs as a single homogeneous segment. There is a need to categorize the Firm Size within MSME and study its effect on various relationships (Brown \&Kaewkitipong, 2009). We used Investments in Equipment (MSME definition for services sector in India, 2006) and No of employees as per travel agency study in Thailand (Brown \&Kaewkitipong, 2009) to categorize retail travel agencies into three size categories - Small Firm, Medium Firm, and Large 
Firms within MSME segment. Thus, we can conceptualize the research hypotheses for moderation as:

H3 (a): When the firm size is larger, the positive effect of the perceived facilitators on the Degree of Digital Use of the retail travel agency strengthens.

H3 (b): When the firm size is larger, the negative effect of the perceived barriers on the Degree of Digital Use of the retail travel agency weakens.

\subsection{Conceptual Model}

The study developed aB2B digital use conceptual model based on proposed hypotheses, and theoretical framework for constructs and their relationships suggested in the findings (see Figure 2).

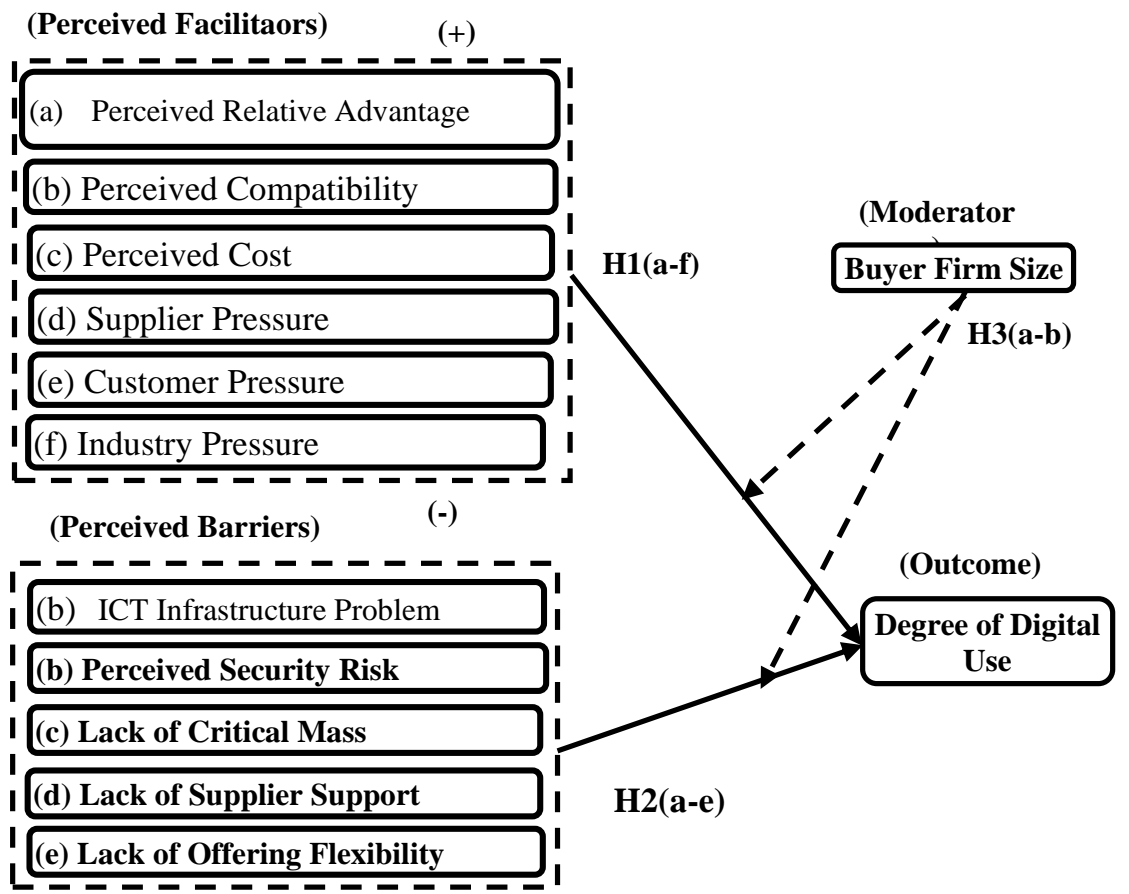

Figure 2 B2B Digital use Conceptual Model

\subsection{Academic Contributions}

\section{Conclusions}

First, the paper developed a process-based conceptualization for digital use in the B2B travel services instead of a unitary outcome variable. Second, the study integrates operational and behavioral theories from diverse subject domains Supply-Chain Management and Social Psychology to develop an Integrated B2B Digital Usages conceptual model. Third, the study identified barriers and facilitators for digital usage distinct from earlier studies on digital adoption. Fourth, the study conceptualized Perceived Cost as Initial Investments plus Operational Cost as a facilitator in digital uses. In contrast, earlier studies have considered Cost as Technology Cost a barrier to 
digital adoption and usages. Fifth, the study also contributes to B2B digital uses in supplier - Intermediary relationships. Sixth, the study contributed to the literature on under-researched domain digital usages of MSMEs in a developing country. Most of the studies on digital adoption and usages focussed on large organizations and SMEs in developed countries.

\subsection{Industry Contributions}

First, practitioners and policymakers will identify key barriers and facilitators in the Indian context,impactingB2Bdigital usages distinct from digital adoption, particularly in supplier-intermediary relationships. Second, the study points to contextual variables of inter-organizational factors that will help online travel suppliers and travel intermediaries work out their digital strategies to strengthen buyer-supplier relationships. Third, the study will also help MSMEs retail travel agencies understand key barriers, facilitators, and strategies to increase digital usages. Fourth, the study suggests that managers should consider all direct and indirect cost components for digital uses, digital adoption that considered only initial technology investments as costs.

\subsection{Limitations and Future Research Directions}

Though the study makes a comprehensive coverage in terms of determinant factors and their relationship with digital usages, there are limitations in the study which can be addressed in future research. The study is conceptual, with a primary objective of theory development. Quantitative research can be initiated to validate the conceptual model. This study can be created in other B2Btravel services contexts with specific travel category focus such as bus travel services, hotel services that have low digital usages. The study is also suitable for digital usage investigations in other B2B service contexts. The study was limited to the MSMEs segment. Adding large travel agencies as respondents will enhance the generalizability of the findings. A longitudinal study for digital usages will trace the process of digital uses across value-chain activities over a defined period. The study can include more contingency variables such as relationship age, firm scope, firm type, product importance to improve the model's generalizability.Very few studies in B2B Digital Usages studied both Antecedents (Barriers \& Facilitators) and Consequences (Outcomes) together in the same service context (Bigne et al., 2008). Researchers can extend the study to include organizational performance such as e-efficiency, e-sales, relationship development as consequents.

\section{References}

1. Andreu, L., Aldas, J., Bigne, J. E. \& Mattila, A.S. (2010). An analysis of ebusiness adoption and its impact on relational quality in a travel agency-supplier relationships. Tourism Management, 31, pp. 777-787.

2. Barney, J. (1991). Firm Resources and Sustained Competitive Advantage. Journal of Management, 17(1), pp. 99-120.

3. Bigne, J. E., Aldas, J., \& Andreu, L. (2008). B2B Services: IT Adoption in travel agency supply chains. Journal of Services Marketing, 22(6), pp. 454-464.

4. Blau, P. M. (1964). Social Exchange Theory. Retrieved September 3, 2007.

5. Blocker, C.P. (2011). Modeling customer value perceptions in cross-cultural business markets. 
6. Brown, D. \&Kaewkitipong, L. (2009). Relative size and complexity: e-business use in small and medium-sized tourism enterprises in Thailand. Journal of Enterprise Information Management, 22(1-2), pp. 212-231.

7. Burt, R. S. (1987). Social Contagion and Innovation: Cohesion Versus Structural Equivalence. American Journal of Sociology, 92(6), pp. 1287-1335.

8. Chahal, H., Gupta, M. \& Lonial, S. (2018) Operational flexibility in hospitals: Scale development and validation. International Journal of Production Research, 56(10), pp 3733-3755.

9. Cook, K. S., \& Emerson, R. M. (1984). Exchange networks and the analysis of complex organizations. Research in the Sociology of Organizations, 3, pp. 1-30.

10. DiMaggio, P., \& Powell, W. W. (1983). The iron cage revisited: institutional isomorphism and collective rationality in organizational fields. American Sociological Review, 48(2), pp. 147-160.

11. Eggert, A., Ulaga, W. \& Schultz, F. (2006). Value creation in relationship life cycle: A quasi-longitudinal analysis. Industrial Marketing Management, 35, pp. 20-27.

12. Eisenhardt, K. M. (1989). Agency Theory: An Assessment and Review. Academy of Management Review, 14(1), pp. 57-74.

13. Emerson, R. M. (1976). Social Exchange Theory. Annual Review of Sociology, 2, pp. 335-362.

14. Ghobakhloo, M., Aranda, D. A. \& Amado, J. B. (2011). Adoption of e-commerce applications in SMEs. Industrial Management \& Data Systems, 111(8), pp. 12381269.

15. Gibbs, J.L. \& Kraemer K.L. (2004). A cross-country investigation of the determinants of scope of e-commerce use: an institutional approach. Electronic markets, 14(2), pp. 124-137.

16. Glaser, B.G. \& Strauss, A. L. (1967). Insight and Theory Development, in Discovery of Grounded Theory. Aldine Publishing Company, Chicago, pp. 251259.

17. Grandon, E.E. \& Pearson, J.M. (2004). Perceptions of strategic value and adoption of e-commerce: a theoretical framework and empirical test, in Currie, W. (Ed.), Value Creation from E-business Models: Issues and Perspectives in Value Creation from E-business Models, Elsevier, Oxford.

18. Hart, P. J. \& Saunders, C. S. (1998). Emerging electronic partnerships: Antecedents and dimensions of EDI use from the supplier's perspective. Journal of Management Information Systems, 14(4), pp. 87-111.

19. Heung, V. (2003). Internet usage by international travelers: reasons and barriers. International Journal of Contemporary Hospitality Management, 15(7), pp. 370378.

20. Huang, L. (2006). Building up a B2B e-commerce strategic alliance model under an uncertain environment for Taiwan's travel agencies. Tourism Management, 27 (6), pp.1308-1320.

21. Hofstede, G. (1997). Cultures and Organisations: Software of the Mind. McGraw-Hill, USA.

22. Homans, G.C. (1958). Social Behavior as Exchange. American Journal of Sociology, 63(6), pp. 597-606. 
23. Iacovou, C.L., Benbasat, I. \& Dexter, A.S. (1995). Electronic data interchange and small organizations: Adoption and impact of technology. MIS Quarterly, 19(4), pp. 465-485.

24. Kaynak, E, Tatoglu, E. \& Kula, V. (2005). An analysis of the factors affecting the adoption of electronic commerce by SMEs. International Marketing Review, 22(6), pp. 623-640.

25. Kenneth, W., Rebecca, M.N. \& Eunice, M. A. A. (2012). Factors Affecting Adoption of Electronic Commerce among Small Medium Enterprises in Kenya: Survey of Tour and Travel Firms in Nairobi. International Journal of Business, Humanities and Technology, 2 (4), pp. 76-91.

26. Lama, S., Pradhan, S. \& Shrestha, A. (2020). Exploration and implication of factors affecting e-tourism adoption in developing countries: a case of Nepal. Information Technology \& Tourism, 22, pp. 5-32.

27. Law, R., Leung, K. \& Wong, R. (2004). The impact of the internet on travel agencies. International Journal of Contemporary Hospitality Management, 16(2), pp. 100-107.

28. Oliveira, T. \& Martins, M. F. (2011). Literature Review of Information Technology Adoption Models at Firm Level. Electronic Journal Information Systems Evaluation, 14(1), pp. 110-121.

29. Ozer, M. (2002). The role of flexibility in online business. Business Horizons, Jan-Feb., pp. 61-69

30. Rahayu, R. \& Day, J. (2015). Determinant Factors of E-Commerce Adoption by SMEs in Developing Country: Evidence from Indonesia. World Conference on Technology, Innovation and Entrepreneurship. Procedia - Social and Behavioural Sciences, 195, pp. 142 - 150.

13. Ramdani, B., Chevers, D. \& Williams, D. A. (2013). SMEs' adoption of enterprise applications: A technology-organization-environment model. Journal of Small Business and Enterprise Development, 20(4), pp.735-753.

14. Raymond, L. (2001). Determinants of Web site implementation in small businesses. Internet Research, 11(5), pp.411-424.

15. Rogers, E. M. (1983). Diffusion of Innovations. 3rd edition. The Free Press, New York.

16. Saghiri, S. S. \& Barnes, S. J. (2016). Supplier flexibility and postponement implementation: An empirical analysis, International Journal of Production Economics, 173, pp 170-183.

17. Shalender K. (2017). Marketing flexibility measurement scale: conceptualization, development and nomological validation. Journal of Strategic Marketing, 25(7), pp 618-628.

18. Shouk, M.A., Megicks, P. \& Lim, W. (2012). Internet Adoption by Travel Agents: a Case of Egypt. International Journal of Tourism Research, 15(3), pp. 298-312.

19. Shree, D., Singh, R.K., Paul, J., Hao, A., \& Xu, S. (2021). Digital platforms for business-to-business markets: A systematic review and future research agenda. Journal of Business Research, 137, 354-365.

20. Sila, I. (2013). Factors affecting the adoption of B2B e-commerce. Electronic Commerce Research, 13, pp. 199-236. 
21. Sila, I. (2015). The state of empirical research on the adoption and diffusion of business-to-business e-commerce. International Journal of Electronic Business. 12 (3), pp.258-301.

22. Simmel, G. (1955). Conflict and the Web of Group Affiliations. Trans. By Kurt H. Wolff and Reinhard Bendix, the Free Press, New York.

23. Simmel, G. (1971). How is society possible? On individuality and social forms. In D.N. Levine (Ed.), University of Chicago Press, pp. 6-22.

24. Taylor, S., Bogdan, R. (1984). Introduction to qualitative research methods: The search for meanings. New York: John Wiley.

25. Teo, T. S. H., Ranganathan, C., \& Dhaliwal, J. (2006). Key dimensions of inhibitors for the deployment of web-based business-to-business electronic commerce. IEEE Transactions on Engineering Management, 53(3), pp. 395-411.

26. Thao, H. T. P. \& Swierczek, F.W. (2008).Internet use, customer relationships and loyalty in the Vietnamese travel industry. Asia Pacific Journal of Marketing and Logistics, 20(2), pp. 190-210.

27. Tornatzky, L. G. \& Fleischer, M. (1990). The Processes of Technological Innovation. Lexington Books, Lexington, MA.

28. Tsai, H. T., Huang, L., \& Lin, C. G. (2005). Emerging e-commerce development model for Taiwanese travel agencies. Tourism Management, 26(5), pp. 787-796.

29. Williamson, O. E. (1975). Markets and Hierarchies: Analysis and Antitrust Implications. Free Press, New York.

30. Wu, F. \& Lee, Y. K. (2005). Determinants of e-communication adoption: the internal push versus external pull factors. Marketing Theory, 5(1), pp. 7-31.

31. Wu, F., Mahajan, V. \& Balasubramanian, S. (2003). An analysis of e-business adoption and its impact on business performance. Journal of the Academy of Marketing Science, 31(4), pp. 425-447.

32. Wu, F., Zsidisin, G. A. \& Ross, A. D. (2007). Antecedents and outcomes of eprocurement adoption: an integrative model. IEEE Transactions on Engineering Management, 54(3), pp. 576-587.

33. Yap, C.S. (1990). Distinguishing characteristics of organizations using computers. Information and management, 18(2), pp. 97-107.

34. Zhu, K. \& Kraemer, K. L. (2005). Post-Adoption Variations in Usage and Value of E-Business by Organizations: Cross-Country Evidence from the Retail Industry. Information Systems Research, 16(1), pp. 61-84.

35. Zhu, K., Kramer, K. L. \& Xu, S. (2006). The process of innovation assimilation by firms in different countries: A technology diffusion perspective on e-business. Management Science, 52(10), pp. 1557-1776.

\section{About Our Author}

Deviprasad Ghosh achieved a Bachelor Degree from Birla Institute of Technology, Mesra Ranchi, Master Degree in Management from S.P. Jain Institute of Management \& Research, Mumbai (1996). He is a certified Project Management Professional (PMP) from Project Management Institute, Pennsylvania, US (2012). He has 25 years of experience as a practitioner, trainer, and consultant in Project \& Product Management. He is currently associated with the Institute of Management Technology Hyderabad as Head of Center for Digital Strategy \& Marketing. 